\title{
Erratum to: \\ Hydrolysis and Dissolution of Amyloids by Catabodies
}

\section{Ville V. Meretoja, Sudhir Paul, and Stephanie A. Planque}

Srinivas V. Kaveri and Jagadeesh Bayry (eds.), Natural Antibodies: Methods and Protocols, Methods

in Molecular Biology, vol. 1643, DOI 10.1007/978-1-4939-7180-0_9, @ Springer Science+Business Media LLC 2017

DOI 10.1007/978-1-4939-7180-0_16

In chapter 9, the below text should have been added to the acknowledgement section:

"Stephanie Planque and Sudhir Paul have a financial interest in Covalent Bioscience, Inc. and patents concerning catalytic antibodies."

The same has been added now.

The online version of the updated original chapter can be found at http://dx.doi.org/10.1007/978-1-4939-7180-0_9 